\title{
A LATE MIDDLE CAMBRIAN SHALLOW-WATER TRILOBITE FAUNA FROM THE MT READ VOLCANICS, NORTHWESTERN TASMANIA
}

\author{
by J.B. Jago and A.W. McNeil
}

(with two text-figures and one plate)

Jago, J.B. \& McNeill, A.W., 1997 (31:viii): A late Middle Cambrian shallow-water trilobite fauna from the Mt Read Volcanics, northwestern Tasmania. Pap. Proc. R. Soc. Tasm. 131: 85-90. https://doi.org/10.26749/rstpp.131.85 ISSN 0080-4703. Department of Applied Geology, School of Engineering, University of South Australia, The Levels, SA, Australia 5095 (JBJ); Geology Department, University of Tasmania, GPO Box 252-79, Hobart, Tasmania, Australia 7001 (AWM).

Near Middlesex Road, $9 \mathrm{~km}$ northeast of the Hellyer mine, northwestern Tasmania, a mineral exploration hole intersects a polymict volcaniclastic conglomerate of the Southwell Subgroup of the Mt Read Volcanics. At depths of $353 \mathrm{~m}$ and $364 \mathrm{~m}$, fossiliferous limestone clasts within this conglomerate contain trilobites, including an unassigned agnostoid cephalon, Amphoton sp., Liopeishania sp., Menocephalites(?) sp., Lisania(?) sp. and an unassigned member of the Dorypygidae, thus suggesting an age of Goniagnostus nathorsti Zone to early Lejopyge laevigata Zone (i.e. Late Middle Cambrian) range. This shallow-water fauna is unusual for the Tasmanian Cambrian, in which most faunas are found in deeper water shales and siltstones. The horizon from which the fossils come is stratigraphically close to a rhyolite with a SHRIMP zircon age of $503.2 \pm 3.8 \mathrm{Ma}$; the usefulness of this figure in terms of the Cambrian time-scale is questioned. Key Words: Cambrian, trilobites, time-scale, Tasmania.

\section{INTRODUCTION}

Numerous Middle and Late Cambrian faunas have been described or reported from Tasmania (e.g. Jago \& Brown 1989, Laurie et al. 1995). Almost all of these faunas are from shale or siltstone sequences, with the only exceptions being a restricted late Middle Cambrian fauna from near Comstock (Jago et al. 1972) and a Late Cambrian fauna from the South Coast (Banks \& Baillie 1989: 188).

In this paper we report, illustrate and briefly describe a new late Middle Cambrian fauna from within limestone blocks found in an exploration hole (DDH MAC20) near the Hellyer mine, northwestern Tasmania (fig.1). The fossils, all trilobites, were found within two limestone clasts from a mass-flow unit within the Southwell Subgroup of the Mt Read Volcanics.

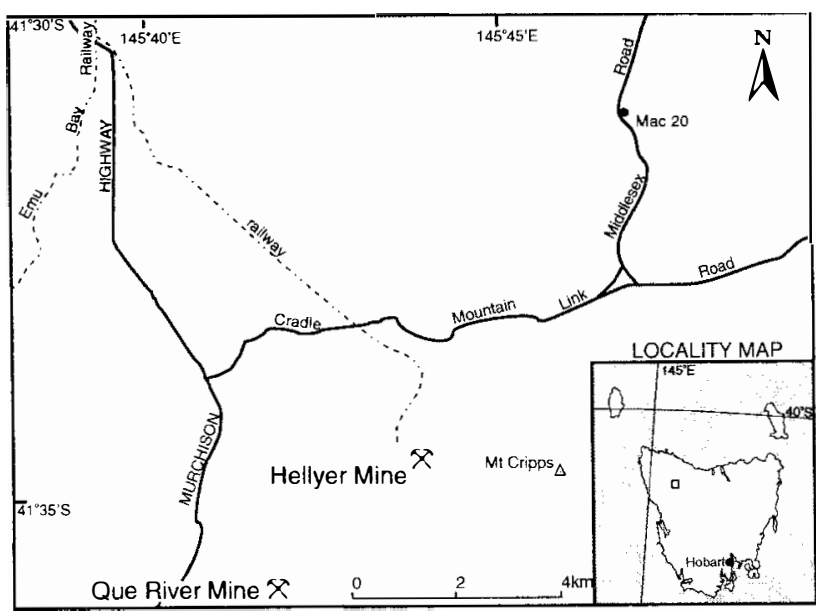

FIG. 1 - Locality map.

\section{STRATIGRAPHY}

Corbett (1992) described and summarised the stratigraphy of the Mt Read Volcanics of western Tasmania. The geology of the Hellyer mine area is shown by Vicary \& Pemberton (1988). The lithostratigraphy, as outlined by Corbett, is shown in figure 2, with pertinent fossil horizons indicated. The fossils described herein come from the Southwell Subgroup, which is bracketed by the Que River Shale (below) and the Mt Cripps Subgroup.

The Que River Shale contains fossils dated in the range Euagnostus opimus Zone to Ptychagnostus punctuosus Zone (Jago 1977, Jago \& Brown 1989, Laurie et al. 1995). The overlying Southwell Subgroup comprises interbedded massflow units, tuffaceous sandstone, siltstone, greywacke and pumiceous breccia. Trilobites in limestone clasts in one of the mass-flow units include an unassigned agnostoid cephalon, Amphoton sp., Liopeishania sp., Menocephalites(?) sp., Lisania(?) sp., and an unassigned member of the Dorypygidae. This is unusual for Tasmanian Cambrian sequences, in that it represents a shallow-water fauna. It is probably of Goniagnostus nathorsti Zone to early Lejopyge laevigata Zone, as discussed below.

The Southwell Subgroup is overlain by the Mt Cripps Subgroup, which comprises three informal units along the Cradle Mountain Link Road (Corbett 1992) correlated by White \& McPhie (1996: fig. 3) with their newly defined units of the Tyndall Group from the Comstock area north of Queenstown. The basal lensoidal unit (equivalent to Lynchford Member, Comstock Formation, of White \& $\mathrm{McPhie)}$ comprises siliciclastic conglomerate and siltstone; above this is crystal-rich volcaniclastic sandstone with intercalated fossiliferous mudstone, minor welded pink ignimbrite and minor andesite lavas (equivalent to Mt Julia Member, Comstock Formation, of White \& McPhie). The fossils, which belong to at least three separate late Middle Cambrian faunas within the late Lejopyge laevigata Zone (Laurie et al. 1995), are currently being studied by 


\begin{tabular}{|c|c|c|}
\hline OWEN CONGLOMERATE & AGES \\
\hline MT CRIPPS \\
SUBGROUP \\
SOUrelate of Tyndall Group)
\end{tabular}

FIG. 2 - Cambrian stratigraphy of the Que River-Hellyer area (modified after Corbett, 1992). The fossils described herein come from limestone clasts within a mass-flow breccia near the middle of the Southwell Subgroup. The SHRIMP age is from Perkins \& Walshe (1993) - the significance of this age is discussed in the text.

C. Bentley (University of South Australia). The top of the Mt Cripps Subgroup comprises volcaniclastic conglomerate and sandstone (Corbett 1992); this is equivalent to the Zig Zag Hill Formation of White \& McPhie (1996).

\section{DDH MAC20}

DDH MAC20 was drilled on Middlesex Road (fig. 1) with the collar coordinates being AMG 398108.2E, $5402853.3 \mathrm{~N}$ on the Pearse topographic sheet. DDH MAC20 is an eastdipping hole drilled by Aberfoyle Resources Limited in 1988 to test for massive sulphide-prospective volcanics (equivalent of the Que-Hellyer volcanics) beneath Tertiary basalt, about $9 \mathrm{~km}$ northeast of the Hellyer mine. It intersected the following in descending order:

0-51.5 $\mathrm{m}$ ( $45 \mathrm{~m}$ true thickness) - Tertiary basalt and sediments

515-184.0 m (101 m) - interbedded polymict volcaniclastic pebble conglomerate to sandstone.

184.0-309.9 $\mathrm{m}(96 \mathrm{~m})$ - interbedded sandstone, grit and pebble conglomerate with minor volcaniclastic mudstone.

Fault contact

309.9-397.5 m (67 m) - polymict volcaniclastic mudstone, sandstone and conglomerate.

All sedimentary facings are up hole and bedding is moderately southwest-dipping (average $50^{\circ}$ dip toward $220^{\circ}$ magnetic from core re-orientations in the interval 196$310 \mathrm{~m}$ ). Limestone clasts have been recovered from the intervals $105-108 \mathrm{~m}$ and $348.9-368.3 \mathrm{~m}$. Trilobites were found by K.D.Corbett (Department of Mineral Resources, Tasmania) in two limestone clasts at $353 \mathrm{~m}$ and $364 \mathrm{~m}$. The latter clast was quite richly fossiliferous; most of the fossils described below come from it. However, as no real difference could be seen in the trilobites from the two clasts they are described below as a single fauna.

The fossil-bearing limestone clasts are in an approximately $16 \mathrm{~m}$ thick, normally graded, polymict volcaniclastic cobble conglomerate. Clasts of sub-angular to sub-rounded limestone, angular quartz-feldspar-phyric rhyolite and dacite, ?shard-rich volcaniclastic mudstone, sericitised ?flamme, grey chert, and black shale are set in a sand-grade matrix composed largely of broken quartz and feldspar crystals and fine quartz-carbonate-sericite altered material of indeterminate origin. The limestone clasts are massive light to dark-grey micrite and dismicrite, with rare patches of secondary quartz and muscovite, scattered biogenic clasts and rare stylolites. This unit is interpreted to be a submarine mass-flow deposit. The limestone clasts were probably partly rounded in a shallow-water environment before incorporation into the flow, while lava clasts may have been derived from hyaloclastic brecciation, and shale, chert, and mudstone may be intraclasts. The source of the limestone may have been a shallow-water carbonate bank fringing a volcano, in much the same way as suggested for shallowwater carbonates of the Comstock Formation near Queenstown (see White \& McPhie 1998: fig. 7a).

The interbedded volcaniclastic mudstones, sandstones and conglomerates, polymict conglomerates, etc., intersected below $51.5 \mathrm{~m}$ in DDH MAC20, are lithological correlates of the Southwell Subgroup, as defined by Pemberton et al. (1991) and Corbett (1992), which outcrops both to the southwest and northeast of DDH MAC20 and is best exposed on the Cradle Mountain Link Road to the southwest (fig. 1). The upper part of the hole correlates with the upper pumiceous breccia and Murrays Road Greywacke (about $300 \mathrm{~m}$ thick on the Cradle Mountain Link Road). The fossiliferous limestone-bearing unit correlates with the lower interbedded mass-flow breccia and tuffaceous sandstone and siltstone unit (fig. 2). This correlation implies that the rocks containing the limestone clasts are younger than the Que River Shale (late Middle Cambrian, Undillan; Gee et al. 1970, Jago 1977) and older than the fossiliferous siltstone and shale of the Mt Cripps Subgroup (Tyndall Group correlate) on the Cradle Mountain Link Road (very late Middle Cambrian, Lejopyge laevigata II Zone-passage zone; Jago in Pemberton et al. 1991). No source of the limestone clasts has been identified. 


\section{BIOSTRATIGRAPHIC AGE OF FAUNA}

The fragmentary nature of the trilobites does not allow an exact biostratigraphic age to be determined. The agnostoid cephalon described herein is of little value in this regard. The majority of the species assigned by Zhang \& Jell (1987) to Menocephalites are found in the Taitzua-Poshania Zone, which these authors correlated within the Goniagnostus nathorsti Zone of northern Australia, although Shergold et al. (1990) suggested correlation with the lower part of the Lejopyge laevigata Zone. Amphoton is well known in the late Middle Cambrian of China, Korea, Antarctica, Australia and New Zealand. Amphoton sp., as described herein, is probably closest to $A$. spinigerum Whitehouse of Queensland. Opik (1982) suggested that $A$. spinigerum is found in the $G$. nathorstiZone. Lisania occurs in the late Middle Cambrian Zhangxian Stage of North China (Zhang \& Jell 1987). Liopeishania is the nominate genus of the Liopeishania Zone, which Zhang \& Jell (1987) correlated with the Lejopyge laevigata Zone of Australia; Shergold et al. (1990) suggested correlation wirh the upper part of the $L$. laevigata Zone. Palmer \& Gatehouse (1972) described Liopeishania spannensis from the late Middle Cambrian Schopfaspis granulosus faunule of Antarctica. Cooper \& Shergold (1991) included this within their Fauna 3, which they considered to be of Floran to Undillan age.

In summary, generic correlation with elsewhere in Australia and China plus the stratigraphic position of the unit suggest an age in the Goniagnostus nathorsti Zone to early Lejopyge Iaevigata Zone interval.

\section{RELEVANCE TO CAMBRIAN TIME-SCALE}

The Cambrian time-scale is in a state of flux (Young $\&$ Laurie 1996), due to a lack of reliable geochronologic dates which can be tied in with the various biostratigraphic scales. It is worth noting the date given for the Middle-Late Cambrian boundary in two recent papers. Young \& Laurie (1996) suggested an age of $498 \mathrm{Ma}$, whereas Gradstein \& Ogg (1996), following Tucker \& McKerrow (1995), suggested a figure of $505 \mathrm{Ma}$. This may not seem particularly significant, but it is of some importance when it is realised that, in the tables given in Young \& Laurie (1996), there are 29 trilobite zones (mainly agnostoid-based) from $506 \mathrm{Ma}$ (base of the Late Templetonian-Floran) to $491 \mathrm{Ma}$ (top of Payntonian), i.e. the average time span for a trilobite zone over this interval is about 520000 years using the Young \& Laurie time-scale.

Perkins \& Walshe (1993) dated a rhyolite lava (their sample 91-278) from what they termed (p.1180) "the Upper Rhyolite sequence north of the Cradle Mountain link road" as having a SHRIMP zircon age of $503.2 \pm$ 3.8 Ma. Although no exact geographic or stratigraphic details were given by Perkins $\&$ Walshe, on their figure 2 they indicated that sample 91-278 came from near the base of the Southwell Subgroup, i.e. at a slightly stratigraphically lower level than the trilobites described herein. However, given that the trilobites come from allochthonous clasts of limestone, there is doubt as to the original stratigraphic relationship between them and sample 91-278.

If the SHRIMP date of $503.2 \pm 3.8 \mathrm{Ma}$ is accepted as correct, then, given its stratigraphic position (fig. 2), it would suggest that the Young \& Laurie (1996) figure of
$498 \mathrm{Ma}$ is more likely to be correct than $505 \mathrm{Ma}$ for the Middle-Late Cambrian boundary. However, the error given by Perkins \& Walshe was a $1 \sigma$ error, which only encompassed a $67 \%$ confidence limit, whereas the current convention is to give a $2 \sigma$ error, which encompasses about a $95 \%$ confidence limit. This would make the Perkins \& Walshe date $503.2 \pm 7.6 \mathrm{Ma}$, a more realistic figure, which would allow the possibility of $505 \mathrm{Ma}$ as the Middle-Late Cambrian boundary date. In either case, particularly the more realistic one, it is evident that the error bar from the geochronologic work covers quite a number of trilobite zones. Extremely precise geochronological dates with good biostratigraphic links in the Middle and Late Cambrian will be required to make significant alterations to the Cambrian time-scale, as well as to the average time-span suggested above for the Middle and Late Cambrian trilobite zones.

\section{SYSTEMATIC PALAEONTOLOGY}

The specimens figured herein were extracted from the limestone pebbles by first heating the pebbles to about $800^{\circ} \mathrm{C}$ for one hour and then quenching them in water. In common with most other Tasmanian Cambrian faunas, the fossils from these pebbles show the effects of tectonic distortion. All figured specimens were photographed after being whitened with magnesium oxide. All catalogue numbers refer to the collections of the Geology Department, University of Tasmania.

\section{Agnostoid gen et sp. indet PI. 1M}

Remarks

One poorly preserved agnostoid cephalon (UTGD125300) is available. It may belong in Peronopsis or allied genus.

\section{Family DORYPYGIDAE Kobayashi, 1935 Dorypygidae gen et $\mathrm{sp}$. indet PI. 1G, H, I}

Material

Two partial cranidia and three partial pygidia (UTGD125305-125308).

Remarks

The fragmentary nature of the material prevents generic assignment.

\section{Family DOLICHOMETOPIDAE Walcott, 1916 Genus AMPHOTON Lorenz, 1906}

Type species

Amphoton steinmanni Lorenz, 1906 (= Dolichometopus deois Walcott, 1905).

\section{Diagnosis}

See Zhang \& Jell (1987): 62. 


\section{Amphoton sp. \\ PI. 1A, B, D}

Material

Two partial cranidia, a pygidium and a hypostome (UTGD125312-125315).

Description

Surface ornament absent. Strongly convex, parallel-sided glabella extends to anterior border. Moderately deep axial furrows. Glabella anterior is broadly rounded. Four pairs of lateral glabella furrows; 1 p deep laterally, bifurcating adaxially with the posterior branch extending almost to the occipital furrow; $2 p$ well developed and directed slightly to the posterior; $3 p$ and $4 p$ furrows shallow, directed slightly to the anterior. Wide deep occipital furrow, occipital ring near the base of what appears to be a strong spine. Anterior border furrow shallow; short anterior border appears to widen abaxially. Arcuate palpebral lobes close to the glabella extending from just forward of the occipital ring to between the $2 p$ and $3 p$ furrows where they appear to meet the axial furrow. Palpebral areas of fixigenae flat; wide palpebral furrows; strap-like posterolateral limbs; long, shallow, posterior border furrow. Pygidium (UTGD 125314, pl.1D) with almost effaced axis of two axial rings and a terminus. Pleural areas almost totally effaced except for one pleural furrow. Shallow, narrow border furrow; wide flat border.

\section{Discussion}

The specimens described herein are probably closest to $A$. spinigerum Whitehouse by virtue of the shape of the glabella and palpebral lobes. However, the palpebral lobes of $A$. spinigerum extend further forwards, and its $1 \mathrm{p}$ furrows do not bifurcate.

\section{Family SOLENOPLEURIDAE Angelin, 1854 Genus MENOCEPHALITES Kobayashi, 1935}

Type species

Menocephalus acanthus Walcott, 1913, p.173, pl.16, figs 4, $4 a, 4 b$.

\section{Menocephalites (?) $\mathrm{sp}$. \\ PI. 1C, E, F}

Material

Three partial cranidia (UTGD125309-125311).

\section{Remarks}

These cranidia have a strongly convex glabella which extends to the anterior border, a well-developed occipital furrow and deep axial furrows. The glabella tapers forwards to a broadly rounded anterior. The fixigenae are strongly convex. Occipital spines absent. They may belong to Menocephalites as diagnosed by Zhang \& Jell (1987: 102). They are similar to the specimens described by Cooper et al. (1996) from northern Victoria Land, Antarctica, as Menocephalites(?) sp., except that the Antarctic specimens have a well-developed occipical spine.

The $1 \mathrm{p}$ furrows of most species of Menocephalites are shallow, but distinct; there is no sign of the $1 \mathrm{p}$ furrows on the specimens figured here. There is no sign of the tuberculate ornamentation present in most species of Menocephalites.

\section{Family ASAPHISCIDAE Genus LIOPEISHANIA Chang, 1963}

Type species

Psilaspis? convexus Endo in Endo \& Resser, 1937, p. 350, pl. 59, figs 1-4.

\section{Remarks}

Four species of Liopeishania have been described. Three of these are from the late Middle Cambrian of China, i.e. $L$. convexus (Endo), L. lubrica (Chang) and L. leura Yang. Palmer \& Gatehouse (1972) described L, spannensis from the late Middle Cambrian of Antarctica.

\section{Liopeishania sp. PI. 1L, N, O}

Material

Five distorted partial cranidia, including UTGD125301125304.

\section{Remarks}

These specimens fit the diagnosis of Liopeishania as given by Palmer \& Gatehouse (1972: 22). The glabella is outlined by shallow axial furrows which become even shallower forwards; the lateral glabella furrows are completely effaced. The glabella stops just short of the narrow shallow anterior border furrow. The absence of eye ridges differentiates it from L. spannensis. The border furrow is not as wide as that of $L$. convexa. However, the limited number and the incomplete and poorly preserved nature of the specimens do not allow either a detailed comparison or a definite species assignment.

\section{Family LISANIIDAE Chang, 1983 \\ Genus LISANIA Walcott, 1911}

Type species

Anomocarella(?) bura Walcott, 1905.

Diagnosis

See Zhang \& Jell (1987): 134

$$
\text { Lisania(?) sp. }
$$$$
\text { PI. 1J, K }
$$

Material

Three fragmentary cranidia (UTGD125316-125318) are tentatively placed in Lisania. The anterior of the cranidium, the path of the facial sutures and the posterolateral limbs cannot be seen. However, the largely effaced glabella which tapers slightly forwards, the position of the anterior end of the palpebral lobe close to the glabella, the shallow axial furrows, and the presence of a low occipital node resemble Lisania. 

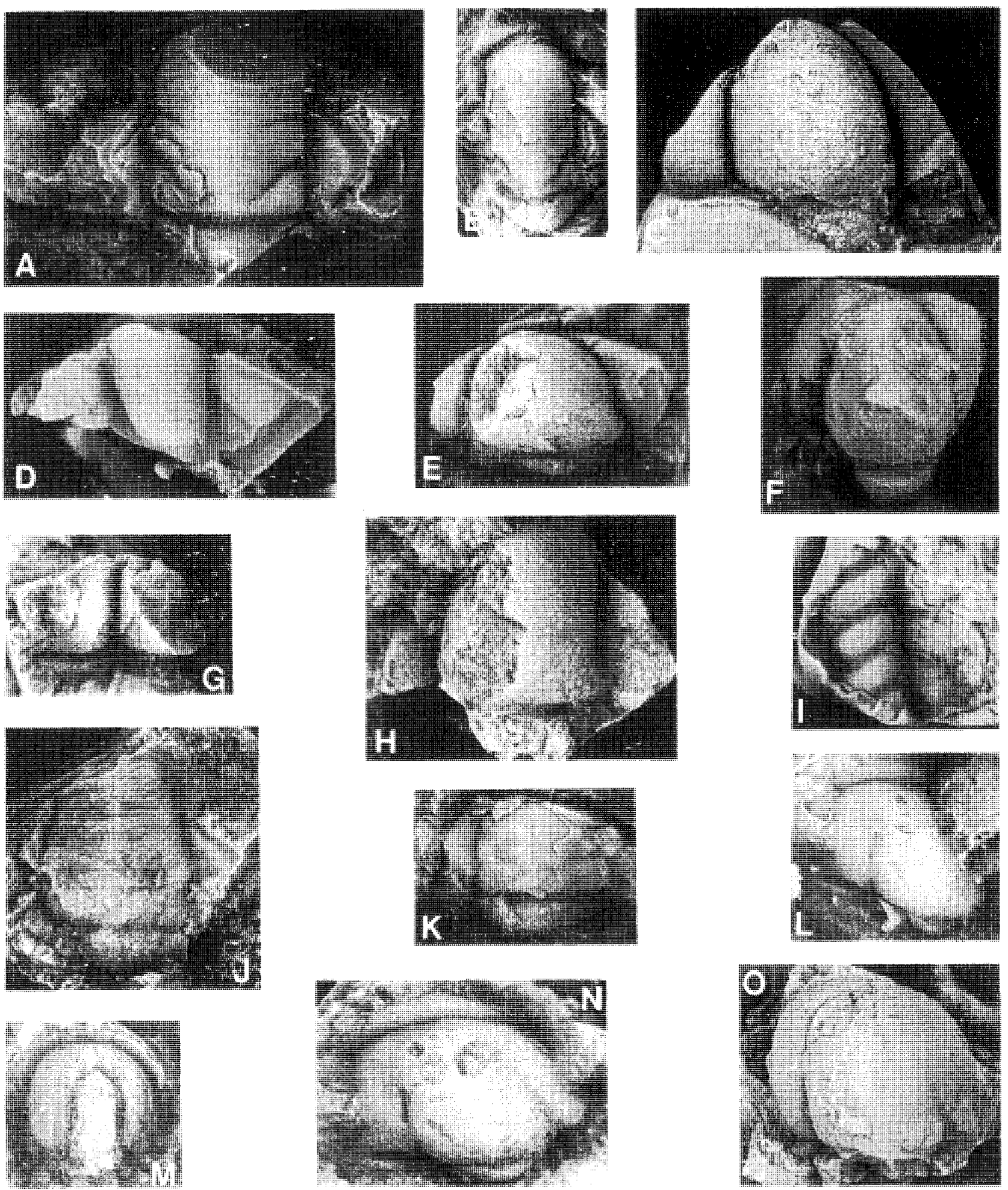

PLATE 1

(A, B, D) Amphoton sp. (A) UTGD125312 partial cranidium, $\times 5$; (B) UTGDI25313 partial cranidium, $\times 7$; (D) UTGD125314 partial pygidium, $\times 8$.

(C, E, F) Menocephalites(?) sp., partial cranidia. (C) UTGD125309, ×5; (E) UTGD125311, ×5; (F) UTGD125310, x4. (G, H, I) Dorypygidae, gen et sp. indet. (G) UTGD125306, partial cranidium, X4; (H) UTGD125305, partial cranidium, $\times 5$; (I) UTGD125307, latex cast of partial pygidium, $\times 7$.

$(J, K)$ Lisania(?) sp., (1) UTGD125316; (K) UTGD125317, partial cranidia, both $\times 5$.

( $L, N, O)$ Liopeishania sp. (L) UTGD125302, latex cast of partial cranidium, $\times 5$; (N) UTGD125301, cranidium, $\times 5$;

(O) UTGD125303 partial cranidium, $\times 5$.

(M) Agnostoid gen. et sp. indet., UTGD125300, cephalon, $\times 11$. 


\section{ACKNOWLEDGEMENTS}

The limestone clasts containing fossils were first recognised by Dr K.D. Corbett (Department of Mineral Resources, Tasmania). Dr J.A. Cooper (Department of Geology and Geophysics, University of Adelaide) is thanked for advice on geochronology. Aberfoyle Resources Limited are thanked for granting access to the core. Two anonymous referees are thanked for their constructive comments. J.B. Jago was supported by an ARC grant.

\section{REFERENCES}

BANKS, M.R. \& BaILLIE, P.W., 1989: Late Cambrian to Devonian. In Burrett, C.F. \& Martin, E.L. (Eds): GEOLOGYAND MINERAL RESOURCES OF TASMANIA. Geol. Soc. Aust. Spec. Publ. 15: 182-237.

Cooper, R.A. \& SHERgold, J.H., 1991: Palaeozoic invertebrates of Antarctica. In Tingey, R.E. (Ed.): GEOLOGY OF ANTARCTICA. Oxford University Press, Oxford: 455486.

CoOper, R.A., JAGO, J.B. \& BegG, J.G., 1996: Cambrian trilobites from Northern Victoria Land, Antarctica and their stratigraphic implications. NZ J. Geol. Geophys. 39: 363387.

CoRbetT, K.D., 1992: Stratigraphic-volcanic setting of massive sulfide deposits in the Cambrian Mount Read Volcanics, Tasmania. Econ. Geol. 87: 564-586.

Endo, R. \& Resser, C.E., 1937: The Sinian and Cambrian formations and fossils of southern Manchoukuo. Manchurian Sci. Mus. Bull. 1.

Gee, C.E., Jago, J.B. \& Qullty, P.G., 1970: The age of the Mt. Read Volcanics in the Que River area, western Tasmania. J. Geol. Soc. Aust. 16: 761-763.

Gradstein, F.M. \& OgG, J., 1996: A Phanerozoic time scale. Episodes 19: 3-5.

JAGO, J.B., 1977: A Late Middle Cambrian fauna from the Que River Beds, western Tasmania. Pap. Proc. R. Soc. Tasm. 111: $41-57$.

Jago, J.B. \& Brown, A.V., 1989: Middle to Upper Cambrian fossiliferous sedimentary rocks. In Burrett, C.F. \& Martin, E.L. (Eds): GEOLOGY AND MINERAL RESOURCES OF TASMANIA. Geol. Soc. Aust. Spec. Publ. 15: 74-83.

Jago, J.B., Reid, K.O., Quilty, P.G., Green, G.R. \& Daily, B., 1972: Fossiliferous Cambrian Limestone from within the Mr. Read Volcanics, Mt. Lyell Mine area, Tasmania. J. Geol. Soc. Aust. 19: 379-382.
Laurie, J.R., Jago, J.B. \& Bao Jinsong, 1995: Review of Tasmanian Cambrian biostratigraphy. Aust. Geol. Surv. Organ. Rec. 1995/69:1-32.

Lorenz, T., 1906: Beitrage zur Geologie und Palaontologie von Ostasien unter besonderer Burucksichtigung der Provinz Schantung im China. Deutsche Geol. Gesell. Zeitschr. 58: $53-108$.

ÖPIK, A.A., 1982: Dolichometopid trilobites of Queensland, Northern Territory and New South Wales. Bull. Bur. Miner. Resour. Geol. Geophys. Aust. 175: 1-85.

Palmer, A.R. \& Gatehouse, C.G., 1972: Early and Middle Cambrian trilobites from Antarctica. US Geol. Surv. Prof. Pap. 456-D.

Pemberton, J., Vicary, M.J. \& Corbett, K.D., 1991: Geology of the Cradle Mountain Link Road-Mt. Tor area. Tasm. Dep. Mines Mt Read Volcanic Proj. Geol. Rep. 4: 94 pp.

PERKINS, C. \& WaLShe, J.E., 1993: Geochronology of the Mount Read Volcanics, Tasmania, Australia. Econ. Geol. 88: 1176-1197.

SHERGOLD, J.H., LAURIE, J.R. \& SUn XiaOWen, 1990: Classification and review of the trilobite order Agnostida Salter 1864: an Australian perspective. Bur. Miner. Resour. Geol. Geophys. Aust. Rep. 296.

Tucker, R.D., \& MCKerrow. W.S., 1995: Early Paleozoic chronology: a review in light of new U-Pb zircon ages from Newfoundland and Britain. Can. J. Earth Sci. 32: 368-379.

Vicary, M.J. \& Pemberton, J., 1988: Geology of the Back Creek-Cradle Mountain Link road area. Tasm. Dep. Mines Mt Read Volcanics Proj: Map 7.

WalcotT, C. D., 1905: Cambrian faunas of China. Proc. US Nat. Mus. 29: 1-106.

WALCOTT, C.D., 1913: The Cambrian faunas of China. In RESEARCH IN CHINA, Vol. 3. Carnegie Inst. Washington Publ. 54: 3-276.

White, M.J. \& McPhie, J., 1996: Stratigraphy and palaeovolcanology of the Cambrian Tyndall Group. Mt Read Volcanics, western Tasmania. Aust. J. Earth Sci. 43: 147-159.

Young, G.C. \& Laurie, J.R. (Eds), 1996: AN AUSTRALIAN PHANEROZOIC TIMESCALE. Oxford University Press: $279 \mathrm{pp}$.

ZHANG WENTANG \& JELL, P.A., 1987: CAMBRIAN TRILOBITES OF NORTH CHINA. Science Press, Beijing: 1-459.

(Accepted 24 June 1997) 